\title{
Studi Variabilitas Upwelling di Laut Banda
}

\section{Galih Tristianto $^{1 *}$, Sri Yulina Wulandari ${ }^{1}$, Agus Anugroho Dwi Suryoputro ${ }^{1}$, Gentur Handoyo ${ }^{1}$ dan Muhammad Zainuri ${ }^{1}$}

\author{
Program Studi Oseanografi, Jurusan Ilmu Kelautan, Fakultas Perikanan dan Ilmu Kelautan, Universitas \\ Diponegoro, Jl. Prof. H. Soedharto, SH, Tembalang, \\ Semarang, 50275 Telp/Fax (024) 7474698 \\ Email: galihtristianto14@gmail.com
}

\begin{abstract}
Abstrak
Laut Banda adalah sebuah cekungan perairan (basin) yang terletak di Kepulauan Maluku, Indonesia. Laut Banda memiliki karakteristik oseanografi yang menarik karena dikelilingi pulau-pulau dan juga selat sebagai jalur perlintasan Arlindo. Sirkulasi dan karakteristik massa air di Laut Banda dipengaruhi kuat oleh angin monsun. Variasi nilai arah dan kecepatan angin monsun berdampak terhadap kejadian coastal upwelling. Tujuan penelitian untuk mengetahui variabilitas upwelling di Laut Banda dan mengetahui hubungan antar parameter upwelling (indeks upwelling,SPL, dan klorofil-a). Penelitian ini menggunakan data komposit bulanan dari satelit AquaMODIS level 3 untuk data SPL dan klorofil-a,data angin reanalisis ECMWF,tahun 2003-2019. Hasil penelitian menunjukkan upwelling di Laut Banda terjadi pada periode April-Oktober dengan puncaknya di bulan Agustus. Rata-rata indeks upwelling mencapai $1.86 \mathrm{~m} 3 / \mathrm{s}$. Dampak kejadian upwelling dapat diidentifikasi melalui SPL yang lebih dingin dan konsentrasi klorofil-a tinggi. Nilai SPL mencapai $26.79{ }^{\circ} \mathrm{C}$ dan konsentrasi klorofil-a adalah $0.614 \mathrm{mg} / \mathrm{m} 3$. Hubungan SPL terhadap indeks upwelling memiliki koefisien korelasi ( $\mathrm{r}=-0.707)$. Hubungan konsentrasi klorofil-a terhadap indeks upwelling memiliki koefisien korelasi ( $\mathrm{r}=0.661)$.
\end{abstract}

Kata kunci : Laut Banda, Monsun, SPL, Klorofil-a, Indeks Upwelling, dan MODIS

\begin{abstract}
The Banda Sea is a basin located in the Maluku Islands, Indonesia. The Banda sea is surrounded by islands and straits. Banda sea is also known as one of Indonesian Throughflow pathways. Characteristics of water mass in the Banda Sea are strongly influenced by the monsoon wind. Variations of monsoon wind direction and speed have an impact on the coastal upwelling. The purpose of the study was to determine the variability of upwelling in the Banda Sea and to determine the relationship between upwelling parameters (upwelling index, SST, and chlorophyll-a). The data of this study are the Aqua-MODIS level 3 satellite data for SST and chlorophyll$a$, and ECMWF windspeed and wind vector reanalysis data. The data were taken from 2003-2019. The results of this research showed that upwelling in the Banda Sea occurred in the April-October period with a peak in August. The average of upwelling index is $1.86 \mathrm{~m}^{3} / \mathrm{s}$. The impact of upwelling can be identified through cooler SST and high chlorophyll-a concentrations. The coolest SST $\left(26.79^{\circ} \mathrm{C}\right)$ and the highest chlorophyll-a concentration (0.614 $\left.\mathrm{mg} / \mathrm{m}^{3}\right)$. The relationship between SST and the upwelling index has a correlation coefficient $(r=-0.707)$ and the relationship of chlorophyll-a concentration with the upwelling index has a correlation coefficient $(r=0.661)$.
\end{abstract}

Keywords: The Banda Sea, Monsoon, SST, Chlorophyll-a, Upwelling Index and MODIS

\section{PENDAHULUAN}

Laut Banda merupakan salah satu perairan yang subur serta berpotensi dalam bidang perikanan dan daerah penangkapan ikan yang terbesar di Indonesia. Hal ini dapat dilihat dari hasil tangkapan ikannya yang begitu besar dan merupakan daerah penangkapan ikan terbesar di Indonesia (Yulia, 2013). 
Hasil tangkapan ikan di Laut Banda pada tahun 2006 berkisar 437.183,40 ton (Sukresno dan Suniada, 2016).

Monsun mempengaruhi sistem sirkulasi massa air di Laut Banda. Selama monsun tenggara (Juni sampai Agustus), air permukaan didorong dari Laut Banda ke dalam Laut Flores, Laut Jawa, dan Laut Cina Selatan. Selama monsun barat laut (Desember hingga Pebruari), air permukaan dari Laut Jawa dan Selat Makassar didorong dari Laut Flores ke Laut Banda Menurut Gordon et al. (1999), bahwa ketika musim timur, arus bergerak ke selatan menuju Samudera Hindia. Pergerakan massa air ke selatan ini akan menyebabkan kekosongan dan akan digantikan oleh massa air dari lapisan bawah. Fenomena ini disebut upwelling. Terjadinya upwelling akan menyebabkan salinitas tinggi, SPL rendah, densitas tinggi, oksigen relatif rendah dan fosfat tinggi terutama pada batas bawah dari lapisan homogen.

Semua penelitian yang telah dilakukan baik skala in situ maupun dengan menggunakan teknologi penginderaan jauh hanya berfokus pada proses terjadinya upwelling dari perubahan fisik, kimia dan biologi tetapi belum disertai perhitungan indeks upwelling. Indeks upwelling ini dikembangkan oleh Bakun (1975) yang ditentukan oleh nilai stres angin dan gaya coriolis Hal ini menjadi menarik untuk melakukan kajian upwelling dengan menggunakan perhitungan indeks upwelling di wilayah Laut Banda.

Penelitian ini bertujuan untuk mengetahui variabilitas upwelling di Laut Banda dan mengetahui hubungan antar parameter (Indeks upwelling SPL,Klorofil di Laut Banda menggunakan data satelit penginderaan jauh AQUA-MODIS dan ECMWF selama periode 2003-2019.

\section{MATERI DAN METODE}

Penelitian ini dilakukan dalam satu tahap, yaitu pengolahan data citra Aqua MODIS level 3 dan data angin Era-Interim ECMWF Data penelitian adalah data komposit yang diperoleh selama rentang waktu 17 tahun dari bulan Januari tahun 2003 hingga bulan Desember 2019. Lokasi penelitian berada di Laut Banda dengan batas area kajian pada koordinat $2,50^{\circ} \mathrm{LS}-6,5^{\circ} \mathrm{LS}$ dan $124,50^{\circ} \mathrm{BT}-130,5^{\circ} \mathrm{BT}$ (Gambar 1).

\section{Pengumpulan Data}

Data Suhu Permukaan Laut dan klorofil adalah data citra satelit Aqua MODIS level 3 dengan resolusi $4 \mathrm{~km}$ dalam format NetCdF (NET Common Data File). Data sebaran Suhu Permukaan Laut dan Klorofil-a adalah data harian selama sepuluh tahun dari tanggal 1 Januari 2003 hingga 31 Desember 2019 dengan citra Suhu Permukaan Laut dan klorofil-a untuk mendapatkan data time series. Data diunduh melalui website https://oceancolor.gsfc.nasa.gov/. Data Suhu Permukaan Laut yang diunduh merupakan citra MODIS daily $11 \mu \mathrm{m}$ SST, sedangkan data klorofil-a adalah daily Chlorophyll OCX.

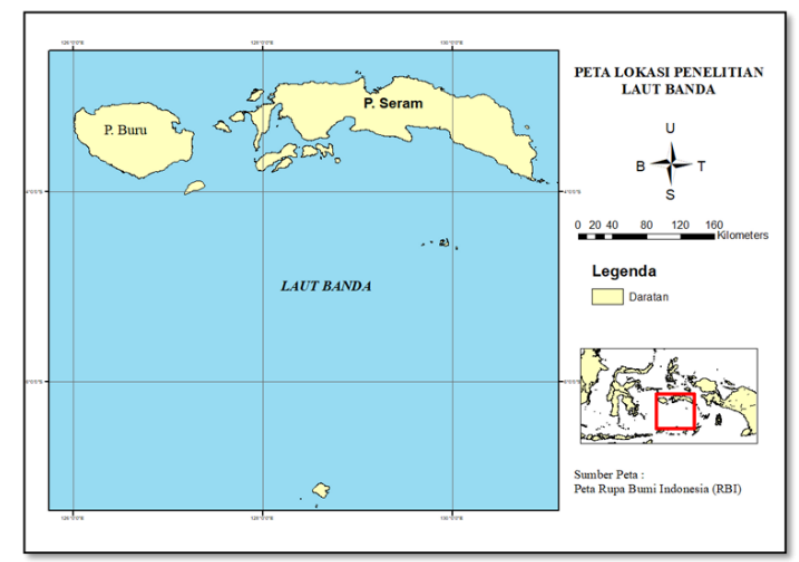

Gambar 1. Peta Lokasi Penelitian dan Pengambilan Data 
Data angin yang digunakan adalah data angin ECMWF yang merupakan data reanalisis dengan resolusi $0.125^{\circ} \mathrm{x} 0.125^{\circ}$ dalam format $\mathrm{NetCdF}$ (NET Common Data File). Data angin selama periode 17 tahun yaitu dari tahun 2003-2019 diunduh melalui website https://www.ecmwf.int/ pada bagian forecasts reanalysis datasets ERA-Interim. Data ini bersifat reanalisis atau analisis ulang dan interpolasi data meteorologi dari pusat pengamatan dan penelitian pusat meteorologi dari seluruh dunia. Data angin terdiri atas dua komponen vektor yaitu, vektor $u$ untuk arah meridioanal barat-timur dan vektor $v$ untuk arah utara-selatan. Setiap masing-masing vektor memiliki nilai kecepatan dalam satuan $\mathrm{m} / \mathrm{s}$ dan arahnya. 10 metre $U$ wind component untuk vektor $u$ dan 10 metre $V$ wind component untuk vektor $v$.

\section{Pengolahan Data}

Data citra Aqua MODIS yang terdiri dari data Suhu Permukaan Laut dan klorofil-a harian serta data angin ECMWF dilakukan perhitungan menjadi komposit bulanan (monthly) dari data harian. Perhitungan ini dilakukan menggunakan software pemrograman GrADS. Menurut Wirasatriya et al. (2017) menyatakan perhitungan komposit bulanan dilakukan untuk melihat variabilitas setiap parameter secara spasial dan temporal. Komposit bulanan dari Suhu Permukaan Laut,klorofil-a dan angin selanjutnya dilakukan perhitungan komposit klimatologis (monthly climatology) dengan software GrADS menggunakan rumus sebagai berikut :

$$
\bar{X}(x, y)=\frac{1}{\mathrm{n}} \sum_{i=1}^{n} x i(x, y, t)
$$

Keterangan :

$\bar{X}(x, y)=$ rata-rata bulanan (monthly climatology)

$x i(x, y, t) \quad=$ Data harian ke-1 pada posisi bujur $(\mathrm{x})$, lintang $(\mathrm{y})$ dan hari ke-t

$\mathrm{n} \quad \quad=$ jumlah data dalam 1 bulan

$\mathrm{i}=1 \quad$ = Hari ke-1

\section{Analisis Data}

Metode analisis data menggunakan analisis perhitungan komputasi dan uji statistitik dasar seperti perhitungan rata-rata,standar deviasi,korelasi,dan determinasi. Hasil analisis akan disajikan dalam bentuk visualisasi gambar, tabel, dan grafik/diagram.

Indeks upwelling pantai (UI) dihitung dengan beberapa tahap formula sebagai berikut: menggunakan data vektor angin untuk mendapatkan gesekan angin (wind stress) tiap komponen angin dengan menggunakan persamaan yang di kemukakan oleh Kutsuwada (1998):

dimana :

$$
\begin{aligned}
\tau x & =\rho C D W u \\
\tau y & =\rho C D W v
\end{aligned}
$$

$$
\begin{array}{ll}
\tau_{x} & =\text { gesekan angin komponen sejajar pantai }\left(\mathrm{kg} / \mathrm{m} / \mathrm{det}^{2}\right) \\
\tau_{y} & =\text { Gesekan angin komponen menegak pantai }\left(\mathrm{kg} / \mathrm{m} / \mathrm{det}^{2}\right) \\
C_{D} & =\text { koefisien Drag }=1.4 \times 10^{-3} \\
\rho & =\text { densitas udara }=1.3 \mathrm{~kg} / \mathrm{m}^{3} \\
W & =\text { kecepatan angin }(\mathrm{m} / \mathrm{det}) \\
u & =\text { komponen kecepatan angin pada sumbu x }(\mathrm{m} / \mathrm{det}) \\
v & =\text { komponen kecepatan angin pada sumbu } \mathrm{y}(\mathrm{m} / \mathrm{det})
\end{array}
$$


Indeks upwelling pantai kemudian dihitung dengan formula dikembangkan dari teori Ekman (1905) dan perhitungan transport Ekman menggunakan persamaan (Pond and Pickard 1983):

$$
\mathrm{Mx}=\frac{\tau_{y}}{f}
$$

dimana :

$\mathrm{Mx} \quad=$ Massa offshore transport ekman $\left(\mathrm{kg} / \mathrm{m} / \mathrm{det}^{2}\right)$

$\tau_{y} \quad=$ Gesekan angin komponen menegak pantai $\left(\mathrm{kg} / \mathrm{m} / \mathrm{det}^{2}\right)$

$\mathrm{f} \quad=$ parameter coriolis $(\mathrm{rad} / \mathrm{det})$

$\mathrm{f} \quad=2 \Omega \sin \theta$

$\Omega \quad=7.29 \times 10^{-5} \mathrm{rad} / \mathrm{det}$

$\Theta \quad=$ posisi lintang $(\mathrm{rad})$

Formula untuk mendapatkan indeks upwelling pantai (UI) menggunakan persamaan (Bakun 1975):

$\mathrm{UI}=M_{x} \frac{1 m \text { coastline }}{1025 \mathrm{~kg} / \mathrm{m}^{3}}\left(\frac{\mathrm{m}^{3}}{\mathrm{~s}} m\right.$ coastline $)$

dimana :

$\mathrm{M}_{\mathrm{x}} \quad=$ Massa offshore transport ekman $\left(\mathrm{kg} \mathrm{det}^{-1} \mathrm{~m}^{-1}\right)$

$\mathrm{UI} \quad=$ Indeks Upwelling $\left(\mathrm{m}^{3} / \mathrm{s} / \mathrm{m}\right.$ coastline $)$

Hubungan antara SPL,konsentrasi klorofil-a, dan UI dikaji dengan menggunakan analisis determinasi dan korelasi dengan menggunakan persamaan $y=a+b x$ dimana $: y=$ UIx $; x=$ SPL dan konsentrasi klorofil-a.

\section{HASIL DAN PEMBAHASAN}

\section{Variasi Nilai Indeks Upwelling di Laut Banda}

Berdasarkan hasil pengolahan data dan perhitungan indeks upwelling (Gambar 2.), secara klimatologis di Laut Banda menunjukkan hasil yang beragam tiap bulannya Menurut Tubalawony et al. (2007), Yunwei et al. (2015) nilai positif (+) dari indeks upwelling menunjukan terjadi pengangkatan massa air (upwelling), sedangkan nilai negatif (-) dari indeks upwelling menunjukan (downwelling).. Sehingga diketahui bahwa upwelling di Laut Banda terjadi pada periode bulan April hingga Oktober. Sedangkan downwelling di Laut Banda terjadi pada bulan November Maret.

Nilai indeks upwelling tertinggi adalah $8,094 \mathrm{~m}^{3} / \mathrm{s}$ yang terjadi pada bulan Agustus dan nilai indeks upwelling terendah adalah $-2,594 \mathrm{~m}^{3} / \mathrm{s}$ terjadi pada bulan Februari. Rata-rata bulanan indeks upwelling tertinggi di Laut Banda juga terjadi pada bulan Agustus dengan indeks sebesar 1,861 m³.s. Indeks upwelling rata-rata bulanan terendah adalah $-0.474 \mathrm{~m}^{3} / \mathrm{s}$ yang terjadi di bulan Februari saat terjadi downwelling. 

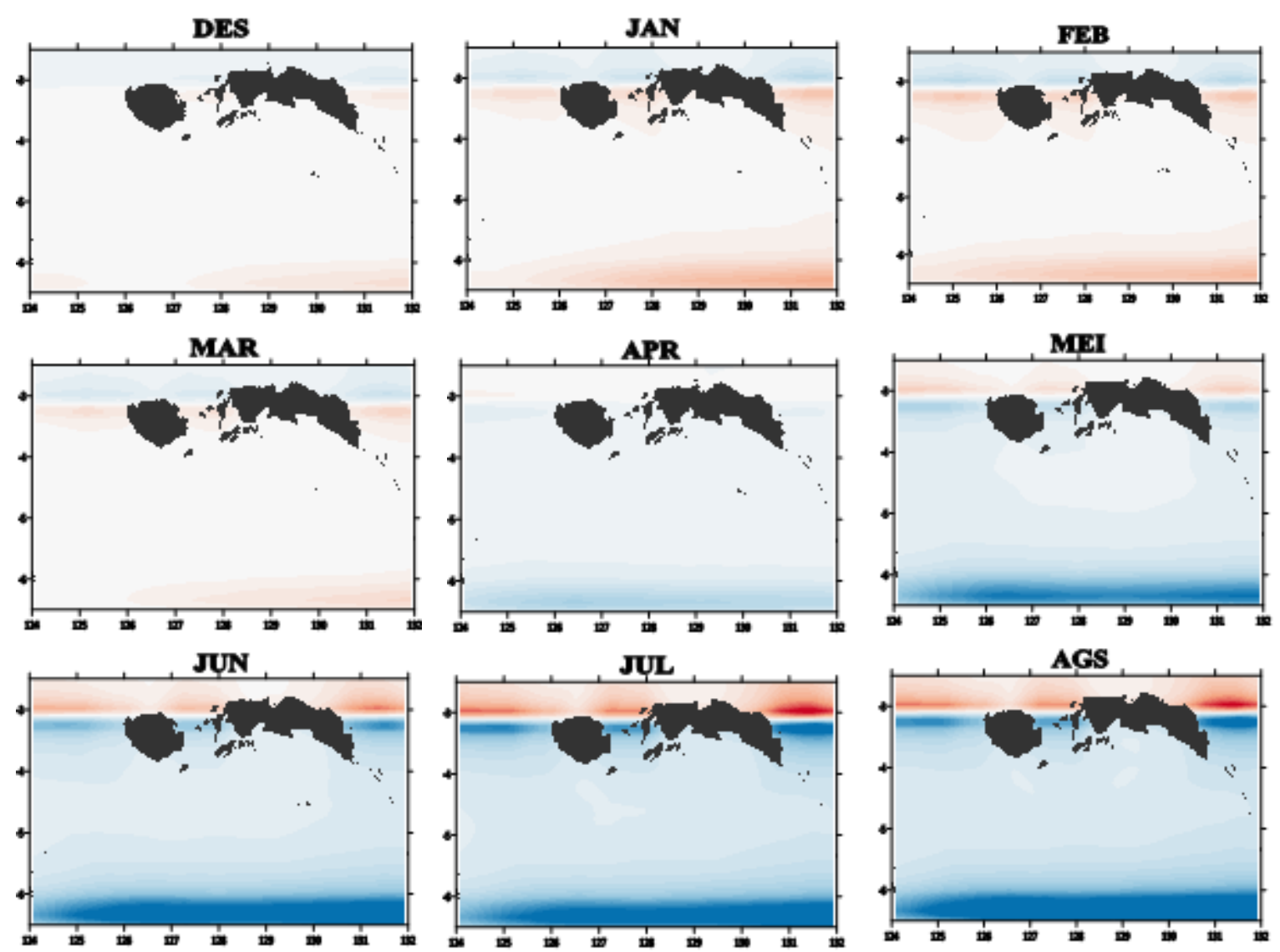

JUL
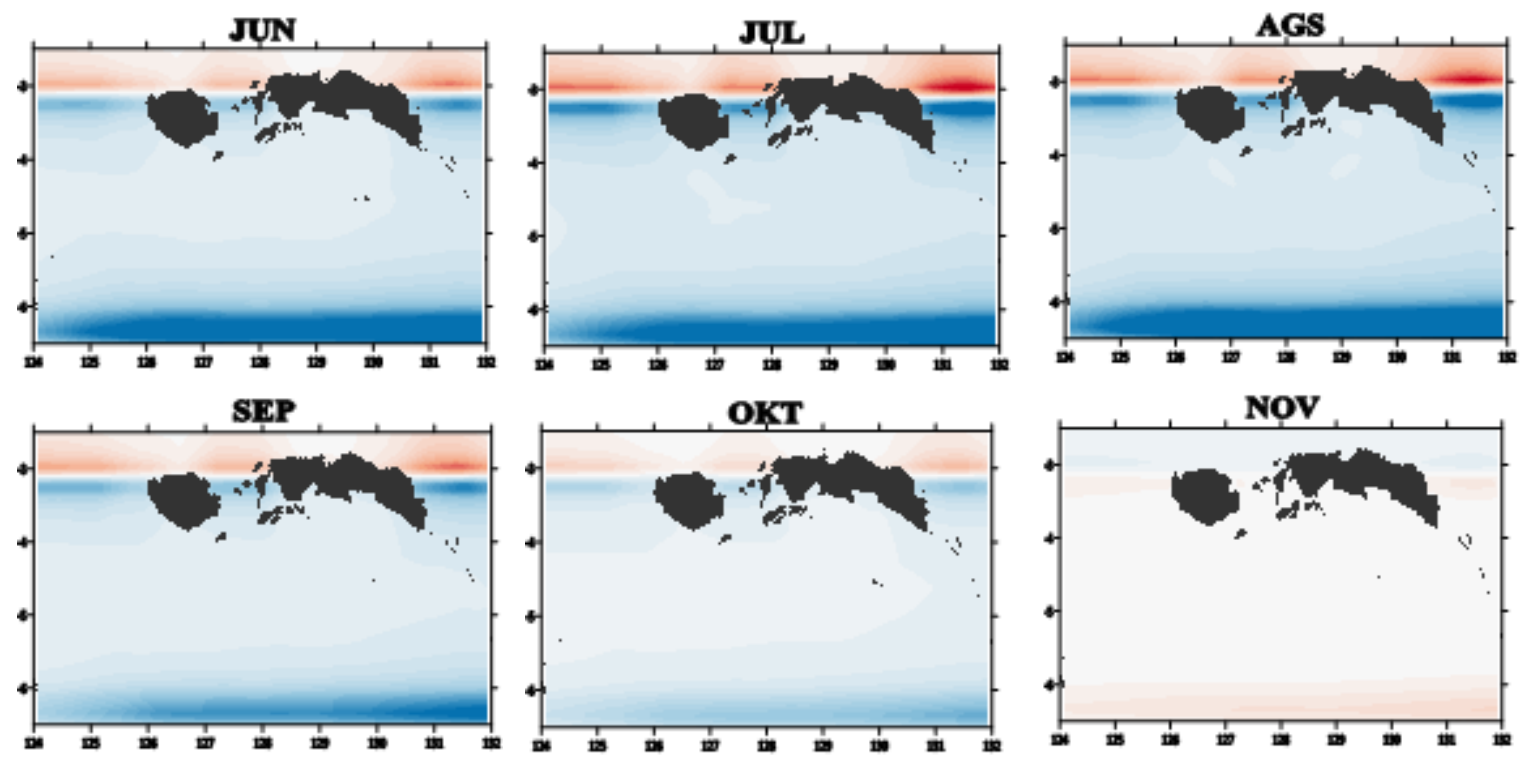

Indeks Upwelling $\left[\mathrm{m}^{3 / \mathrm{s}}\right]$

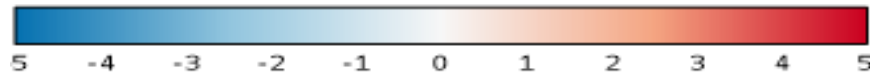

Gambar 2. Sebaran Indeks Upwelling di Laut Banda secara Klimatologis Bulanan

Indeks upwelling bernilai rendah di dekat pantai dan nilainya akan meningkat ke arah laut lepas karena kecepatan angin yang semakin tinggi kecepatanya dari wilayah on-shore ke off-shore. Selain itu indeks upwelling juga bernilai cukup tinggi di daerah selat. Selat antar kepulauan di Laut Banda adalah jalur perlintasan Arlindo yang umumnya memiliki arus yang kuat. Sprintall dan Liu (2005) menyatakan bahwa aliran dari Laut Banda menuju Samudera Hindia mencapai puncak ketika musim timur yaitu Juli sampai September, pada waktu tersebut akan menyebabkan naiknya massa air dingin dari lapisan bawah sehingga suhu permukaan akan menjadi lebih rendah pada bulan-bulan tersebut. Sehingga ekman transport efektif untuk mendorong massa air ke selatan saat musim timur. 


\section{Variasi Suhu Permukaan Laut (SPL) di Laut Banda}

Suhu permukaan laut pada tiap bulan di Laut Banda nilainya bervariasi (Gambar 3). Nilai suhu permukaan laut (SPL) terendah adalah $25,54{ }^{\circ} \mathrm{C}$ yang terjadi di bulan Agustus. SPL tertinggi adalah $33,16^{\circ} \mathrm{C}$ yang terjadi di bulan November. SPL rata-rata bulanan tertinggi terjadi di bulan Desember dengan nilai mencapai $30,25^{\circ} \mathrm{C}$ dan rata-rata SPL terendah adalah bulan Agustus dengan nilai $26,79{ }^{\circ} \mathrm{C}$.
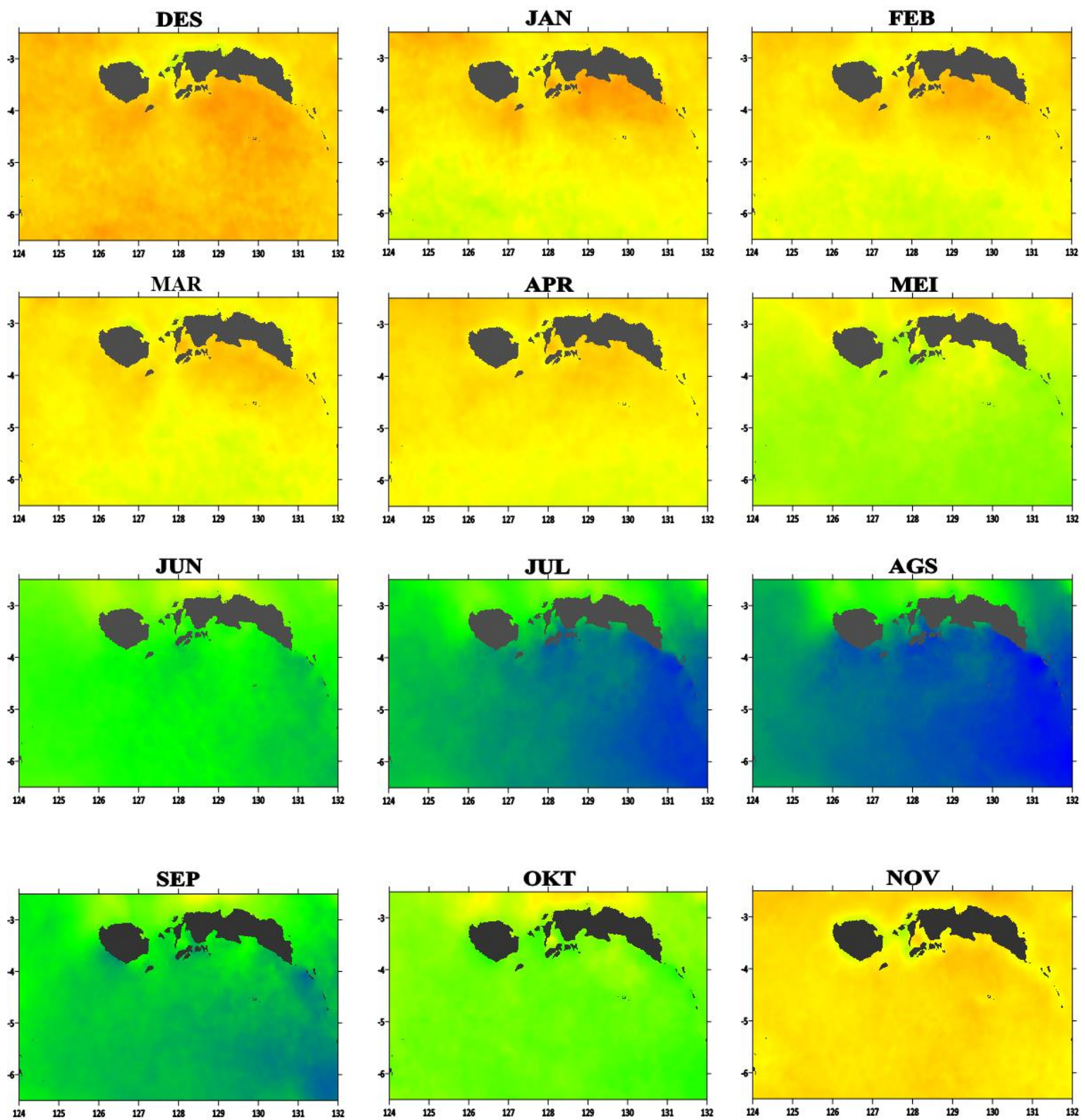

Suhu Permukaan Laut $\left[{ }^{\circ} \mathrm{C}\right]$

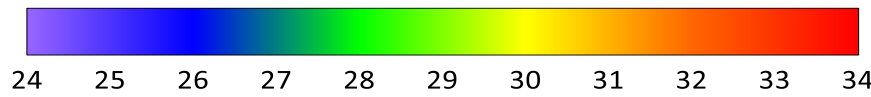

Gambar 3. Sebaran Suhu Permukaan Laut (SPL) di Laut Banda secara Klimatologis Bulanan

Suhu permukaan laut (SPL) di Laut Banda pada periode upwelling, April hingga Okober cenderung lebih dingin daripada bulan-bulan lainnya. Suhu permukaan laut bulan April masih cenderung hangat. Hal ini diduga disebabkan karena kecepatan angin yang rendah saat itu. Menurut 
Munandar et al. (2016) kecepatan angin mempengaruhi penetrasi cahaya matahari ke kolom perairan dan menurunya tingkat evaporasi akan menyebabkan suhu permukaan laut lebih tinggi.

Memasuki bulan Mei suhu permukaan laut mulai mengalami penurunan seiring dengan peningkatan intensitas upwelling. Penurunan suhu permukaan laut terus berlanjut pada bulan Juni,Juli,dan Agustus. Bulan Agustus SPL di Laut Banda mencapai nilai minimumnya bersamaan dengan intensitas upwelling yang tertinggi pada periode itu. Intensitas upwelling mulai melemah dan kecepatan angin menurun di bulan September hingga Oktober. Akibatnya suhu permukaan laut bulan September dan Oktober mulai meningkat.

Nilai suhu permukaan laut saat downwelling bulan November hingga Maret relatif lebih hangat bila dibandingkan dengan SPL pada bulan-bulan upwelling terjadi. Bulan November adalah musim peralihan dari musim timur ke musim barat. SPL bulan November lebih tinggi bila dibandingkan bulan April yang juga bulan pergantian musim. Tingginya suhu permukaan laut pada bulan November diduga disebabkan oleh rendahnya kecepatan angin dan tingkat evaporasi saat itu.

Pada musim Barat, bulan Desember SPL masih tinggi dan mencapai puncak tertinggi sepanjang tahun. Bulan Januari-Februari suhu permukaan laut sedikit mengalami penurunan bahkan pada beberapa lokasi nilainya dibawah $29^{\circ} \mathrm{C}$. Hal ini diduga disebabkan oleh peningkatan kecepatan angin,tutupan awan, dan presipitasi (hujan) pada saat itu bersamaan dengan musim penghujan. Suhu permukaan laut kemudian mulai meningkat kembali di bulan Maret pada akhir periode downwelling di Laut Banda.

\section{Variasi Konsentrasi Klorofil-a di Laut Banda}

Nilai konsentrasi klorofil-a di Laut Banda tiap bulannya terlihat bervariatif (Gambar 4). Konsentrasi klorofil-a tertinggi terjadi di bulan Juli dengan nilai $1,763 \mathrm{mg} / \mathrm{m}^{3}$. Konsentrasi klorofil-a terendah adalah $0,052 \mathrm{mg} / \mathrm{m}^{3}$ yang terjadi di bulan Maret. Konsentrasi klorofil-a rata-rata bulanan tertinggi terjadi pada bulan Agustus dengan nilai rata-rata mencapai $0,614 \mathrm{mg} / \mathrm{m}^{3}$. Rata-rata bulanan klorofil-a terendah terjadi di bulan Maret dengan nilai $0,145 \mathrm{mg} / \mathrm{m}^{3}$.

Konsentrasi klorofil-a di Laut Banda pada periode upwelling (April-Oktober) nilainya cukup tinggi. Bulan April konsentrasi klorofil-a masih rendah dan mulai meningkat di bulan Mei hingga Agustus. Hal ini disebabkan adanya proses upwelling di Laut Banda. Menurut Yuhendrasmiko et al. (2016) upwelling menyebabkan peningkatan konsentrasi klorofil-a karena massa air yang terangkat dari lapisan bawah kaya akan nutrien yang bermanfaat bagi pertumbuhan fitoplankton dan proses fotosintesisnya.

Selain upwelling, kecepatan angin juga berpengaruh terhadap konsentrasi klorofil-a. Menurut Saraswata et al. (2013) kecepatan angin yang tinggi saat musim timur (Mei-Oktober) menyebabkan konsentrasi klorofil-a di perairan meningkat karena angin mampu membangkitkan arus dan gelombang sehingga terjadi proses pengadukan (mixing) pada kolom perairan mengangkat nutrien dari bawah ke permukaan.

Konsentrasi klorofil-a tertinggi di Laut Banda terjadi pada bulan Agustus sejalan dengan intensitas upwelling dan kecepatan angin tertinggi yang juga terjadi di bulan tersebut. Penurunan konsentrasi klorofil-a terjadi di bulan September dan Oktober saat intensitas upwelling dan kecepatan angin mulai berkurang.

Konsentrasi klorofil-a di Laut Banda saat downwelling (November-Maret) nilainya cukup rendah dengan rata-rata bulanannya kurang dari $0,2 \mathrm{mg} / \mathrm{m}^{3}$. Konsentrasi klorofil-a pada bulan November bernilai rendah dilepas pantai namun konsentrasi klorofil-a di pesisir selatan sedikit lebih tinggi karena masih ada pengaruh upwelling pada bulan sebelumnya yaitu bulan Oktober. 
Konsentrasi klorofil-a di Laut Banda pada bulan Desember hingga Maret mulai menurun, dan justru klorofil-a terlihat tinggi di pesisir utara. Hal ini dikarenakan adanya upwelling yang terjadi di Laut Seram. Menurut Gordon et al. (1999) bahwa upwelling dan sinking (downwelling) terjadi bergantian dalam satu tahun di pesisir selatan dan utara pulau Buru dan Seram. Selain itu, menurut Rasyid (2009) konsentrasi klorofil-a pada musim barat juga dipengaruhi oleh tingginya presipitasi saat musim penghujan yang akan meningkatan run off dari daratan untuk menyuplai nutrien ke daerah pantai dan muara sungai.

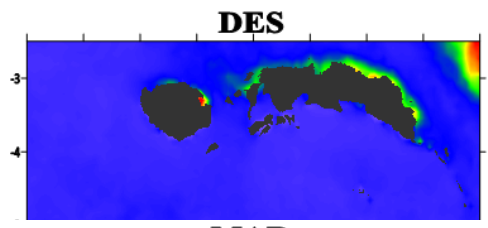

MAR
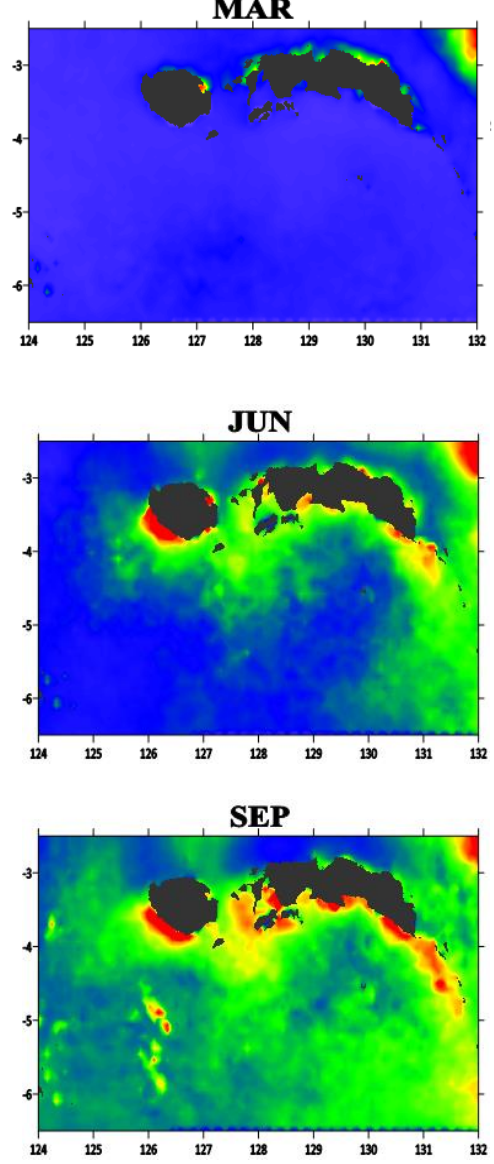

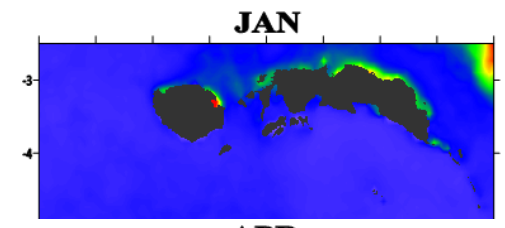

APR

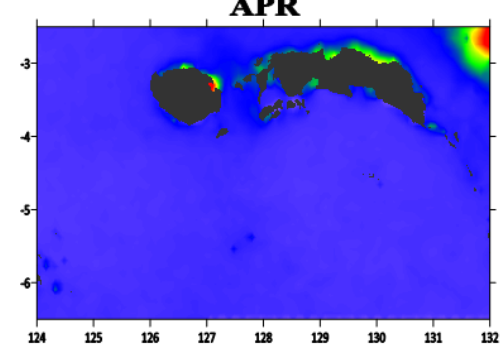

JUL
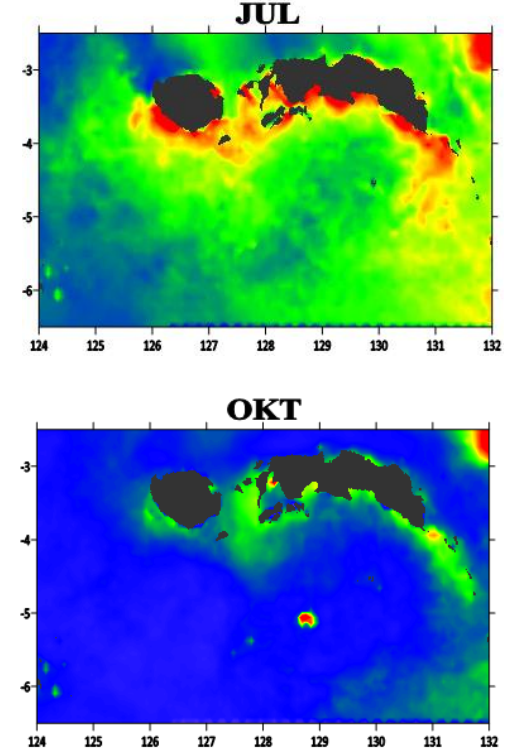

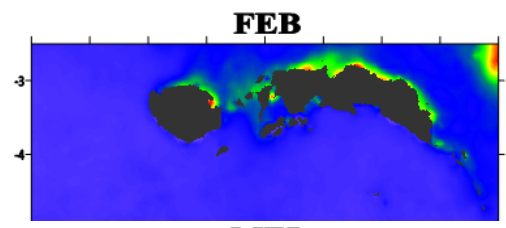

MEI

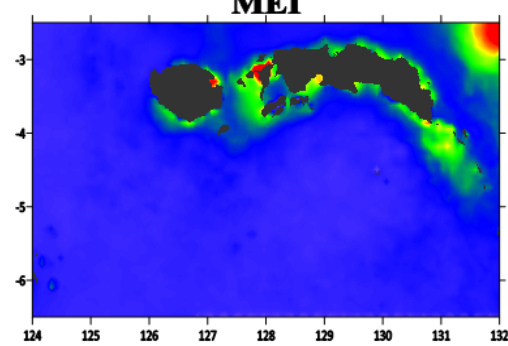

AGS
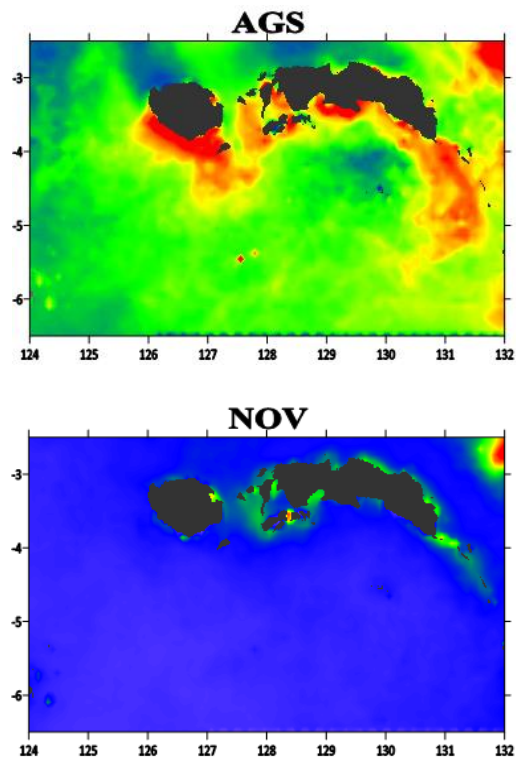

Klorofil-a $\left[\mathrm{mg} / \mathrm{m}^{3}\right]$

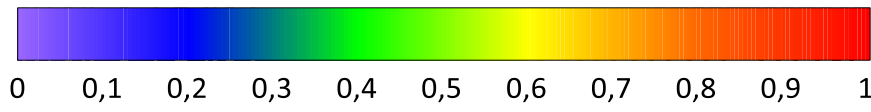

Gambar 4. Sebaran Konsentrasi di Laut Banda secara Klimatologis Bulanan

\section{Hubungan Upwelling dengan Indikator Suhu Permukaan Laut dan Klorofil-a di Laut Banda}


Suhu permukaan laut (SPL) dan konsentrasi klorofil-a adalah dua indikator yang diamati dalam indikasi terjadinya upwelling di suatu perairan. Selama periode upwelling di Laut Banda (April Oktober) indeks upwelling,SPL, dan klorofil-a memiliki pola yang tetap (Gambar 5). Penurunan nilai suhu permukaan laut (SPL) dan peningkatan konsentrasi klorofil-a yang signifikan setiap bulannya sejalan dengan kenaikan nilai indeks upwelling. Hal ini sesuai dengan Kunarso et al. (2011) yang menyatakan bahwa upwelling yang terjadi di perairan ditandai dengan SPL yang rendah dan konsentrasi klorofil-a yang tinggi.

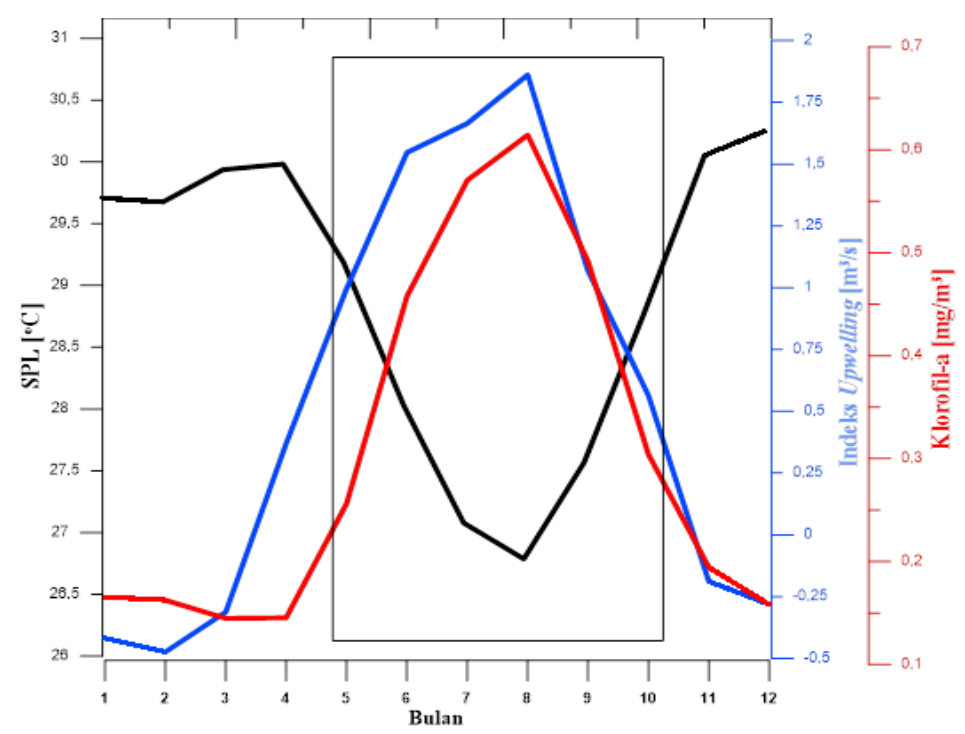

Gambar 5. Grafik Gabungan Indeks Upwelling,SPL,dan Klorofil-a terhadap Bulan di Laut Banda

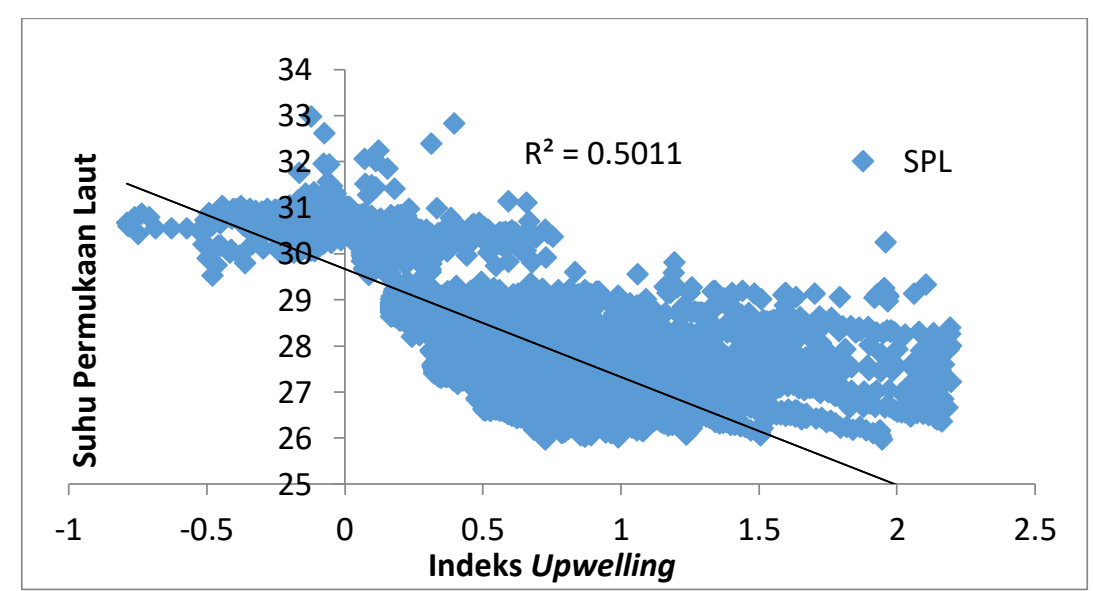

Gambar 6. Grafik Korelasi Suhu Permukaan Laut terhadap Indeks Upwelling

Hasil analisis menunjukkan bahwa hubungan antara indeks upwelling dengan SPL di Laut Banda (Gambar 6) memiliki hubungan korelasi yang kuat $(r=-0.707)$ dan determinasi $\left(r^{2}=0.5011\right)$. Hal ini sesuai dengan penelitian Izumo et al. (2008) yang mengemukakan bahwa hubungan antara indeks upwelling dengan SPL memiliki pola yang linier dan berkorelasi negatif. Korelasi bernilai negatif bahwa semakin meningkat SPL maka nilai indeks upwelling-nya semakin kecil dan sebaliknya semakin rendah nilai SPL maka nilai indeks semakin besar. Sehingga dapat dikatakan bahwa sebaran indeks upwelling 
yang tinggi akan mempengaruhi sebaran SPL yang rendah. Nilai determinasi 0.5011 menunjukkan bahwa suhu permukaan laut di Laut Banda, sebesar $50.11 \%$ nilainya dipengaruhi oleh adanya upwelling sedangkan sisanya dipengaruhi faktor lain.

Hubungan antara konsentrasi klorofil-a dengan indeks upwelling (Gambar 7) adalah eksponensial. Hasil analisis menunjukkan bahwa korelasi indeks parameter ini memiliki korelasi hubungan yang cukup kuat $(\mathrm{r}=0.661)$ dan determinasi $\left(\mathrm{r}^{2}=0.4364\right)$. Korelasi indeks upwelling dan klorofil-a menunjukkan korelasi positif, artinya saat terjadi peningkatan indeks upwelling maka konsentrasi klorofil-a juga akan meningkat dan sebaliknya. Nilai determinasi menunjukkan $43.64 \%$ konsentrasi klorofil-a di Laut Banda nilainya dipengaruhi oleh upwelling.

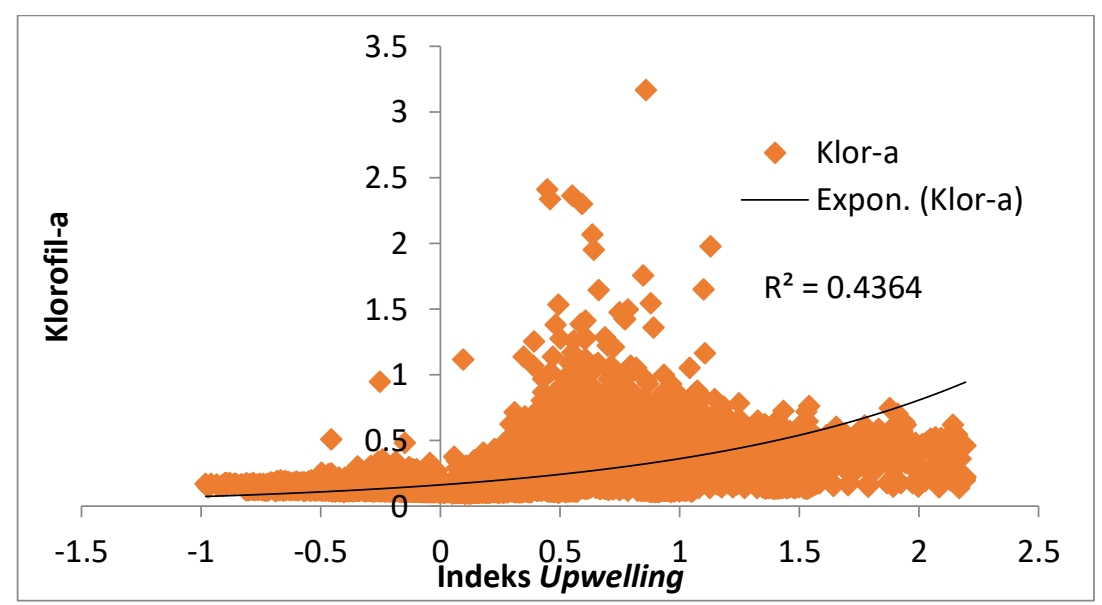

Gambar 7. Grafik Korelasi Konsentrasi Klorofil-a terhadap Indeks Upwelling

Nilai determinasi dan korelasi klorofil-a terhadap indeks upwelling lebih rendah bila dibandingkan dengan korelasi dan determinasi SPL dengan indeks upwelling. Hal ini terjadi karena proses upwelling akan meningkatkan pengkayaan nutrien di perairan tersebut, kemudian baru diikuti terjadinya peningkatan konsentrasi klorofil-a. Menurut Samada et al. (2016) ketika terjadi sebaran indeks upwelling yang tinggi tidak secara langsung mempengaruhi konsentrasi klorofil-a tinggi, tetapi ada jeda waktu (time lag) sebelum terjadi peningkatan konsentrasi klorofil-a.

\section{KESIMPULAN}

Variabilitas upwelling di Laut Banda berfluktuatif setiap bulannya. Proses upwelling dan downwelling di Laut Banda terjadi secara bergantian setiap tahun karena perubahan angin muson. Periode November - Maret terjadi downwelling di Laut Banda, sedangkan bulan April - Oktober terjadi upwelling. Puncak upwelling di Laut Banda terjadi pada bulan Agustus dengan rata-rata indeks upwelling sebesar $1.86 \mathrm{~m}^{3} / \mathrm{s}$. Upwelling di Laut Banda menyebabkan SPL menjadi turun dan konsentrasi klorofil-a meningkat. Suhu permukaan laut rata-rata terendah yang tercatat saat upwelling adalah 26.79 ${ }^{\circ} \mathrm{C}$ dan konsentrasi klorofil-a rata-rata tertinggi mencapai $0.614 \mathrm{mg} / \mathrm{m}^{3}$. Intensitas upwelling di Laut Banda memiliki tingkat hubungan yang berbeda dengan suhu permukaan laut (SPL) dan klorofil-a. Nilai korelasi indeks upwelling dengan SPL adalah $(\mathrm{r}=-0.707)$ dan nilai korelasi indeks upwelling dengan klorofil-a sedikit lebih rendah yaitu $(\mathrm{r}=0.661)$.

\section{DAFTAR PUSTAKA}


Bakun A. 1975. Daily and Weekly Upwelling Indices West Coast of North America. NOAA.

Gordon, A. L., R.D. Susanto, and F. Ami. 1999. Throughflow within Makassar. J. Geophys. Res. Lett., 26 (21): 3325-3328.

Izumo T, C.B Montegut, J.J Luo, S.K Behera, S. Masson, T. Yamagata. 2008. The Role of the Western Arabian Sea Upwelling in Indian Monsoon Rainfall Variability. Juornal of Climate., 21(21):56035623.

Kunarso, Hadi S., Ningsih N.S. dan Baskoro M.S. 2011. Variabilitas Suhu dan Klorofil-a di Daerah Upwelling pada Variasi Kejadian ENSO dan IOD di Perairan Selatan Jawa sampai Timor. Jurnal Ilmu Kelautan Undip., 16(3):171-180.

Kutsuwada K. 1998. Impact of Wind/Wind-Stress Field in the North Pacific Constructed by ADEOS/NSCAT data. J. Oceanogr., 54(1): 443-456.

Pond S and GL Pickard. 1983. Introductory Dynamical Oceanography. Second edition. Pergamon Press. New York.

Rasyid, A. 2009. Distribusi Klorofil-a pada Musim Peralihan Barat-Timur di Perairan Spermonde Propinsi Sulawesi Selatan. . Jurnal Sains \& Teknologi., 9(2):125-132.

Samada, W., Amrana, M. A., Muhiddina, A. H., dan Tambarua, R. 2016. Dinamika Spasial Temporal Sebaran Klorofil-a Perairan Selat Makassar Kaitannya dengan Lokasi Penangkapan Ikan. In Seminar Nasional Pengelolaan Perikanan Pelagis-MEXMA., 35(1): 35-39.

Saraswata, A. G., Subardjo, P., \& Muslim, M. 2013. Pengaruh Monsun Terhadap Distribusi Suhu Permukaan Laut Dan Klorofil-A Di Perairan Selatan Bali. Journal of Oceanography., 2(1): 79-87.

Sprintall, J. and W.T. Liu. 2005. Ekman Mass and Heat Transport in the Indonesian Seas. Journal of Oceanography. Oceanography Society - Rockville. USA., 18(4):88-97.

Sukresno, B. dan K.I. Suniada. 2016. Observasi Pengaruh ENSO terhadap Produktivitas Primer Bersih dan Potensi Perikanan dengan Menggunakan Data Satelit Di Laut Banda. Majalah Ilmiah Globe., 10(2):97-107.

Tubalawony, S., R. F. Kaswadji, M. Purba, S.Woutthuyzen dan D. Soedharma, 2007. Dampak Proses Fisik Terhadap Sebaran Klorofil Secara Spasial dan Temporal di Perairan Barat Sumatera dan Selatan Jawa - Sumbawa. J.Ichthyos., 6 (2): 97-104.

Wirasatriya, A., A.R. Setiawan dan P. Soebardjo. 2017. The Effect of ENSO on the Variability of Chlorophyll-a and Sea Surface Temperature in the Maluku Sea. IEEE Journal of Selected Topics in Applied Earth Observations and Remote Sensing., 1(10): 5513-5518.

Yuhendrasmiko, R., Kunarso, dan Wirasatriya, A. 2016. Identifikasi Variabiltas Upwelling Berdasarkan Indikator Suhu dan Klorofil-a di Selat Lombok. Journal of Oceanography., 5(4): 530-537.

Yulia, K. E. M. 2013. Variabilitas Klorofil-a dan Beberapa Parameter Oseanografi Hubungannya Dengan Monsoon, ENSO dan IOD di Laut Banda. [Tesis]. Program Studi Magister Sains, Program Pascasarjana, Institut Pertanian Bogor. $87 \mathrm{hlm}$.

Yunwei, Y., Z. Ling and C.Chen. 2015. Winter Coastal Upwelling off Northwest Borneo in the South China Sea. Acta Oceanol.Sin., 34(1): 3-10. 